\title{
Alizarin Red S-Alcian Blue Staining for Regenerated tail of Common House Gecko (Hemidactylus frenatus)
}

\author{
Rakhmiyati $^{1 * *}$, Muhammad Ja'far Luthfi' \\ ${ }^{1}$ Postgraduate Program, Universitas Sebelas Maret \\ Jalan Ir. Sutami 36 A, Surakarta, 57126, Tel. +62271-646994, Fax. +62271-646655, Indonesia \\ ${ }^{2}$ Department of Biology Education, Faculty of Science and Technology, UIN Sunan Kalijaga \\ J1. Marsda Adisucipto, No. 1 Yogyakarta 55281, Tel. +62-274-540971, Fax. +62-274-519739, Indonesia. \\ Author correspondency*: \\ miarakhmiy@gmail.com
}

\begin{abstract}
Common House Gecko (Hemidactylus frenatus) is one of reptiles that have ability to autotomy their tails. Tail autotomy is a mechanism to protect it self from predators. After the tail broke, there will be wound healing on the tail which is then followed by a tail regeneration event. Original tail and regenerate tail is very different morphologically and anatomically. The original tail is composed of bones while the tail of the regenerate is composed of cartilage. Histochemical staining using Alizarin Red-S Alcian Blue was done to differentiate bone and cartilage. This method will stained bones red while the cartilage will stained blue.
\end{abstract}

Keywords: Common house gecko (Hemidactylus frenatus); Autotomy; Alizarin Red- S Alcian Blue; cartilage; bone (osteon)

\section{INTRODUCTION}

The tail of the common house gecko (Hemidactylus frenatus) is flat and tapered at the tip. In the dorsal area there are fine scales and no spots (Takahashi, 2009). These scales are brownish yellow (Pratiwi, 2009). The tail comprised of procoel vertebrae (Maria, 1998).

Autotomy is a capacity breaking of the tail, either part or whole of the tail when the animal is chased or captured (Lin \& Lin, 2017; Luthfi, 2002; Soesilo, 1992). In general, autotomy can be said to be a structural adaptation to minimize tissue damage and ease the wound healing process (Gilbert et al, 2013). Tail autotomy is a self-protection mechanism that can be carried out by Lacertilian (Londono et al, 2017). According to Pratt (1946) if the tail is held it will cause uneven pressure of muscle contraction across all segments and excessive pressure will occur on the tail held resulting breaking. Tail function in lacertilian are as a regulator of balance and movement, storing energy, sexual and reproductive function (Jagnandan et al, 2014).

The next step is regeneration, which is the ability of living things to replace body parts lost due to injury, tear, damage or autotomy (Kimball, 1983; Soesilo, 1992). Regeneration process occurs through several stages, namely the wound healing stage, cell proliferation, angiogenesis, formation of extracellular matrix, blastema formation stage and stage of tail differentiation and growth (Soesilo, 1992; Alibardi, 2009; Gilbert et al, 2013; Lozito \& Tuan, 2016; Jacyniak et al, 2017). Mesenchymal cells and several cells accumulate below the wound epidermis form blastema (Alibardi, 2017). In order to observe the structure of regenerated tail of common house gecko (Hemidactylus frenatus) it is necessary to make the original tail and tail regenerate preparations using Alizarin Red S-Alcian Blue staining.

\section{MATERIALS AND METHODS}

Common house gecko were sacrified using chloroform, then the tails were cut at its base. The tail were then immersed in $96 \%$ alcohol solution for 4 days, skinned, and immersed in $96 \%$ alcohol solution for 2 days. The tails were soaked in acetone for 3 days, then soaked in a dye solution for 4 days ( 1 volume $0.3 \%$ Alcian Blue in $70 \%$ alcohol +1 volume $0.1 \%$ Alizarin Red S in $95 \%$ alcohol +1 volume of glacial acetic acid +17 alcohols $75 \%$ volume) and then washed with distilled water. After that the tails were immersed in $1 \% \mathrm{KOH}$ for 3 days. The tails were soaked in a mixture of glycerin and $1 \% \mathrm{KOH}$ with a ratio of $20 \%: 80 \%$; $50 \%$ : $50 \%$; $80 \%$ : $20 \%$ successively, each for 2 days and after that the preparations were keep in pure glycerin to be observed.

\section{RESULTS AND DISCUSSION}

Data obtained from observations on the original tail and the regenerate tail of the wall lizard stained with Alizarin Red S-Alcian Blue showed a difference between the original tail bone and the regenerated one. The original 
tail is composed of bones (osteon) where as of regenerate is of cartilage.

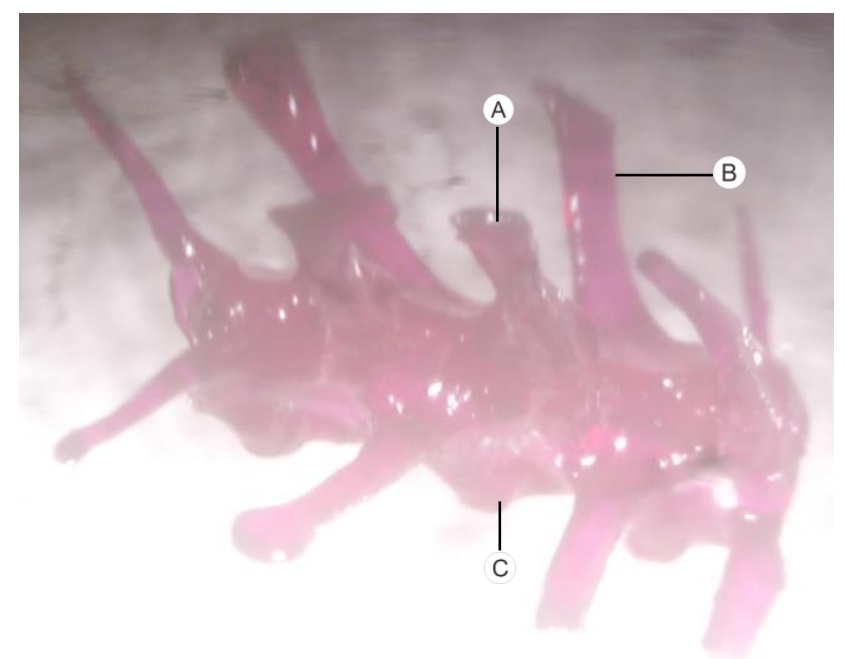

Figure 1. Whole tail preparation of common house gecko (Hemidactylus frenatus). Alizarin Red S-Alcian Blue (dorsal view). Magnification 3X. (A). Processus dorsal; (B). Processus transversal; (C). Processus ventral.

The vertebral type of common house gecko (Hemidactylus frenatus) is procoelous. Its centrum is concave or curves anteriorly and is convex posteriorly. The original tail has procesus transversus as a posterior attachment of the muscle, while the anterior part of the muscle is attached to the myoseptum (Figure 1).

Viewed from the ventral side, there are prezygapophysis, postzygapophysis, centrum and cevron bone.

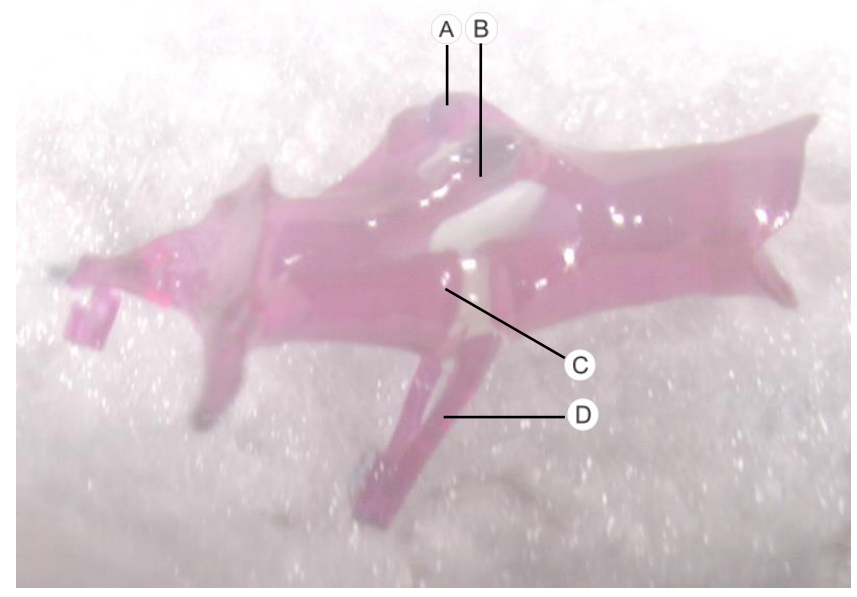

Figure 2. Whole tail preparation of common house gecko (Hemidactylus frenatus). Alizarin Red S-Alcian Blue (ventral view). Magnification 3X. (A). Postzygapophysis; (B). Prezygapophysis; (C). Centrum; (D). Cevron bone.

Seen from the ventral part of the tail, there is a joint of prezygapophysis found in the anterior vertebrae and postzygapophysis joints found in the posterior vertebra
(Figure 2). These two joints are only located in the dorsal part.

The original tail stained red along the vertebrae caudales because it is composed of bone tissue starting from the base of the tail to the tip of the tail (Figure 3). The processus vertebrae are found along the vertebrae caudales, but its size reduced posteriorly.

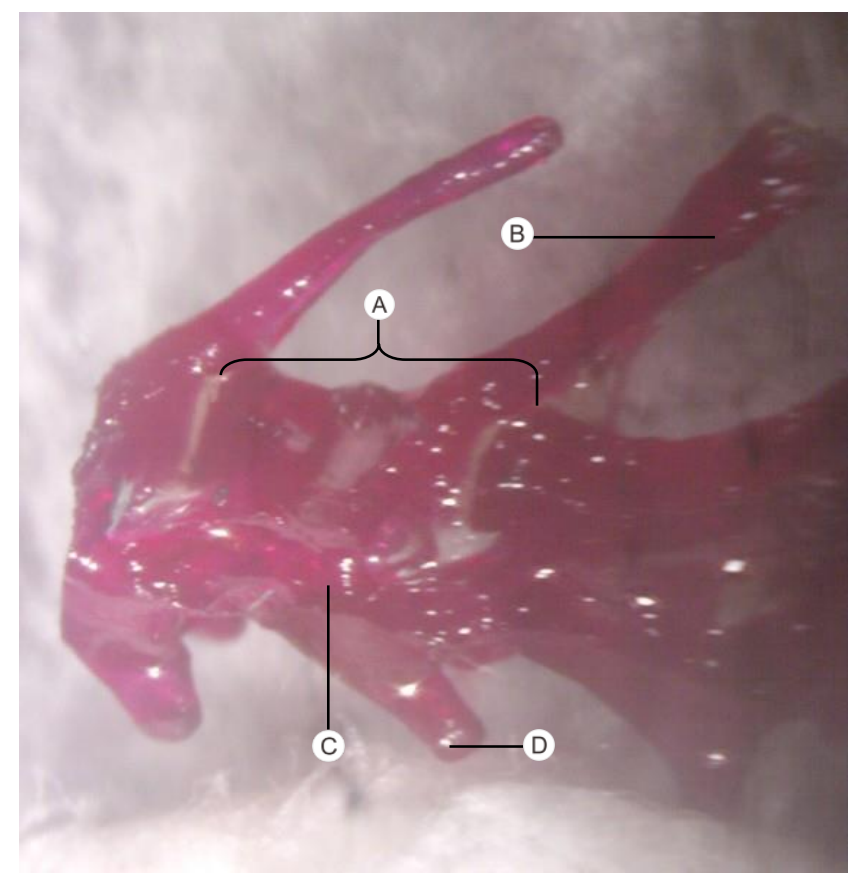

Figure 3. Whole tail preparation of common house gecko (Hemidactylus frenatus). Alizarin Red S-Alcian Blue (transversal view). Magnification 3X. (A). Autotomy plane; (B). Processus dorsal; (C). Processus transversal; (D). Processus ventral.

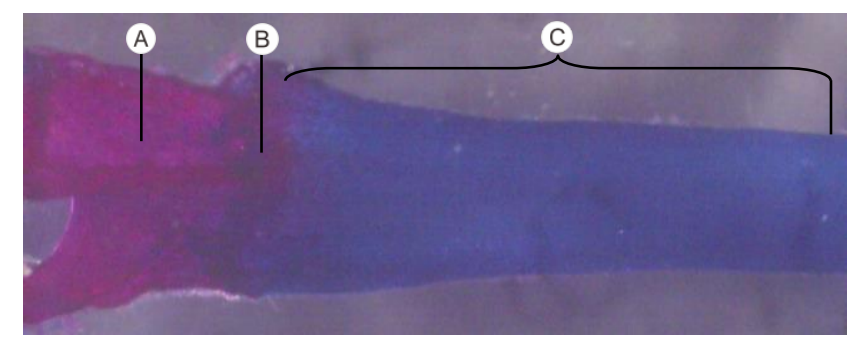

Figure 4. Whole preparation of immature regenerate tails of common house gecko (Hemidactylus frenatus) of Alizarin Red S-Alcian Blue (magnification 7X). (A). Bone of original tail; (B). Border (crack area) between the original tail and the regenerate tail; $(\mathrm{C})$. Cartilagineus tube of immature regenerate tail.

The dark red color in the original tail indicates that the tail has many calcium ions which bind to the Alizarin Red $S$ dye, where as the immature one will stained blue because the it does not have calcium ions. This is consistent with the statement expressed by Lozito \& Tuan (2016). 


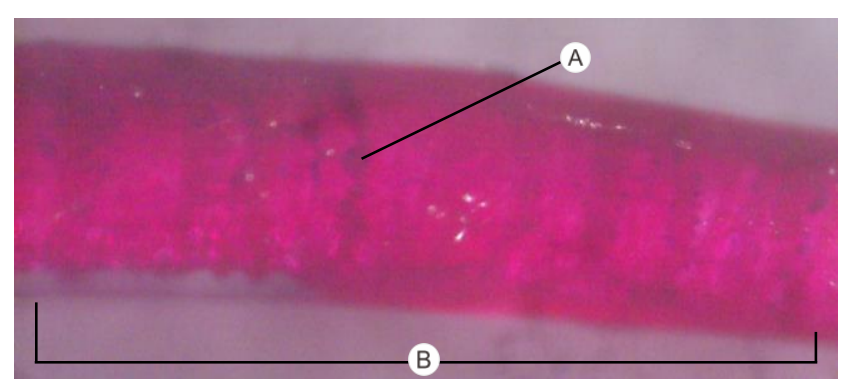

Figure 5. Whole preparations of old regenerate tails (Hemidactylus frenatus). Alizarin Red SAlcian Blue (magnification 11,25X). (A). Cracks; (B). Cartilago tube of old regenerate tail.

In the mature regenerate tail, cartilaginous tube looks red because calcification has occurred. Along the mature regenerate tail there are cracks that can break the tail (Figure 5). Viewed from any side (dorsal, ventral, and transverse), the regnerate tail will look the same color.

\section{CONCLUSION}

From the results of this study it can be concluded that the original tail is composed of bones (osteon) and has complex parts, namely the transverse processes, dorsal processes, ventral processes, prezygapophysis, postzygapophysis, centrum, cevron bone, vertebral cracks (autotomic plane). Where as the regenerate tail is composed of cartilage which is tube like shaped and will calcified in mature regenerate and developed crack in a very matured one.

\section{REFERENCES}

Alibardi. 2009. orphological and Cellular Aspects of Tail and Limb Regeneration in Lizards. 1 st Edition, pp: 1-49.

Alibardi. 2017. Review: Biological and Molecular Differences between Tail Regeneration and Limb Scarring in Lizard: An
Inspiring Model Addressing Limb Regeneration in Amniotes. Journal of Ekperimental Zoology (Molecular and Developmental Evolution). 00B: 1-22.

Gilbert et al, 2013. The Anatomy and Histology of Caudal Autotomy and Regeneration in Lizards. Physiological and Biochemical Zoology. Vol. 86(6):631-644.

Jagnandan et al, 2014. Tail autotomy and subsequent regeneration alter the mechanics of locomotion in lizards. The Journal of Experimental Biology 217: 3891-3897.

Jacyniak et al, 2017. Tail regeneration and other phenomena of wound healing and tissue restoration in lizards. Journal of Experimental Biology. Vol. 220, pp: 2858-2869.

Kimball, 1983. Biologi. Edisi kelima. Jakarta: Erlangga.

Lin \& Lin, 2017. Tail regeneration after autotomy revives survival: A case from a long-term monitored lizard population under avian predation. The Royal Society Publishing. pp: 1-9.

Londono et al, 2017. cartilage and Muscle Cell Fate and Origins during lizard Tail regeneration. Frontiers in Bioengineering and Biotechnology. Vol. 5, no. 70, pp: 1-9.

Lozito \& Tuan, 2016. Lizard tail skeletal regeneration combines aspects of fracture healing and blastema-based regeneration. Development. Vol. 143, pp: 2946-2957.

Luthfi, M. J. 2002. Kalsifikasi Skeleton Aksial dan Kemampuan Autotomi Regenerat Ekor Kadal (Mabouya multifasciata Kuhl). Tesis. Universitas Gadjah Mada (Unpublished).

Maria, B. 1998. Struktur Vertebrae Caudales pada 5 Species Anggota Sub Ordo Lacertilia. Thesis. Universitas Gadjah Mada (Tidak Dipublikasikan).

Pratiwi, 2009. Struktur Organ Reproduksi dan Seksual Dimorfisme in Hemidactylus frenatus Dumeril \& Bibron, 1836; Cosymbotus platyurus (Schneider, 1792); \& Gekko gecko Linnaeus, 1758. Thesis Universitas Gadjah Mada (Unpublished).

Soesilo, N. P. 1992. Proses Regenerasi Ekor Kadal (Mabouya multifasciata Kuhl). Biologi, Vol. 1, No. 4: 169-175.

Takahashi, 2009. Preferensi Pakan Cicak rumah (Hemidactylus frenatus, Gray 1825) dan Tokek (Gekko gecko, Linnaeus 1758) di Gamping, Sleman, Daerah Istimewa Yogyakarta. Thesis. Universitas Gadjah Mada (Unpublished) 